\title{
UK Renal Registry 20th Annual Report: Introduction
}

\author{
Katharine Evans, Rhodri Pyart, Retha Steenkamp, Tim Whitlock, Catherine Stannard, \\ Rachel Gair, James McCann, Julie Slevin, James Medcalf, Fergus Caskey \\ UK Renal Registry, Bristol, UK
}

\section{Background}

The UK Renal Registry (UKRR) was established by the Renal Association in 1995 with the primary aim of collating data centrally from all adult UK renal centres to improve the care of patients with end stage renal disease (ESRD). Although originally limited to patients on renal replacement therapies (RRT) - dialysis treatments and kidney transplant recipients - the UKRR has now started to collect all cases of acute kidney injury (AKI) in primary and secondary care and all cases of advanced chronic kidney disease (CKD) in secondary care not on dialysis. This will greatly improve understanding of how patients progress to ESRD. Children on RRT were initially captured by a separate registry established by the British Association for Paediatric Nephrology, but this activity passed over to the UKRR from 2009.

The Bristol-based UKRR team of 18 data analysts, systems developers, statisticians and researchers manage data collection, analysis and reporting on approximately 8,000 new patients and 63,000 existing patients on RRT each year. A regionally based team of six project managers and administrators deliver the three main Think Kidneys programmes as described in the Improvements and innovations in patient care section below.

The UKRR has an active and involved patient council of approximately 15 members who meet with representatives of the UKRR team four times a year in Birmingham. They discuss issues of importance to patients, such as clearer communication of the UKRR's work, how

\begin{tabular}{ll}
\hline KARGER & $\begin{array}{l}\text { C } 2018 \text { The UK Renal Registry } \\
\text { Published by S. Karger AG, Basel Karger }\end{array}$ \\
Fax +4161306 1234 & Open access \\
E-Mail karger@karger.com & $\begin{array}{l}\text { This article is licensed under the Creative Commons Attribution- } \\
\text { www.karger.com/nef }\end{array}$ \\
$\begin{array}{l}\text { NonCommercial-NoDerivatives 4.0 International License (CC BY- } \\
\text { NC-ND) (http://www.karger.com/Services/OpenAccessLicense). } \\
\text { Usage and distribution for commercial purposes as well as any } \\
\text { distribution of modified material requires written permission. }\end{array}$
\end{tabular}

personal data are handled securely and ideas for research projects. A recent outcome is that plain English summaries of annual report chapters are now available on the UKRR website (https://www.renalreg.org/) and accompanying infographics are being developed.

The UKRR has entered an exciting phase with the development of clinical informatics and data now used not only for audit purposes, but also for randomised controlled trials and quality improvement and innovation in patient care.

\section{Data collection}

Most data are collected from renal centres via automatic quarterly downloads (figure 1). English, Welsh and Northern Irish renal centres send their data directly to the UKRR, where much work is undertaken to identify and resolve errors and inconsistencies before detailed statistical analyses are conducted. Scottish data are collected, validated and published by the Scottish Renal Registry before they are shared with the UKRR. AKI data, on the other hand, are sent directly from hospital laboratories to the UKRR on a monthly basis. The continuing development of the UK Renal Data Collaboration (UKRDC) is leading to significant changes in data collection as detailed in the Clinical informatics section below. Currently, for those patients signed up to PatientView (PV), data flow daily from renal centres through the UKRDC into PV. For enrolled patients, data also flow to the National Registry of Rare Kidney Diseases (RaDaR). PV is a mobile-friendly platform that gives

\footnotetext{
Katharine Evans

UK Renal Registry, Southmead Hospital, Southmead Road,

Bristol, BS10 5NB, UK

Email: renalregistry@renalregistry.nhs.uk
} 


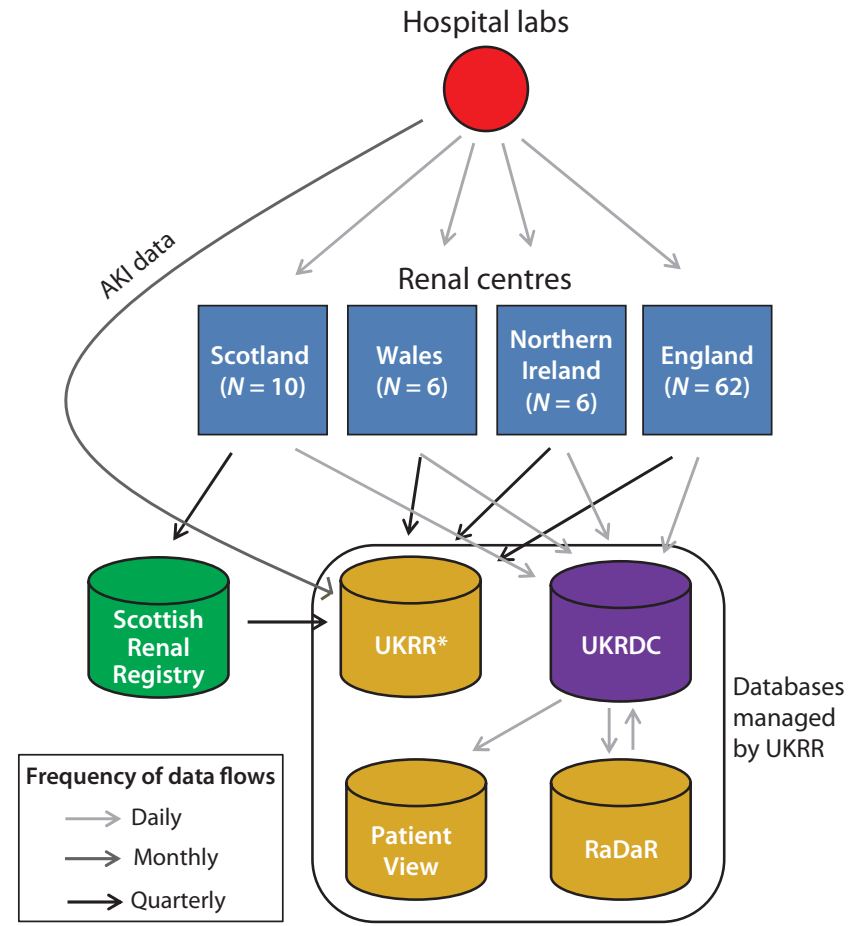

Fig. 1. Frequencies and directions of patient data flows between hospital laboratories, renal centres and databases

*The UKRR database includes the British Association for Paediatric Nephrology database

AKI - acute kidney injury; RaDaR - National Registry of Rare Kidney Diseases; UKRDC - UK Renal Data Collaboration; UKRR - UK Renal Registry

patients real-time access to much of the information in their renal electronic health record, including blood results, medication lists and letters. $\mathrm{RaDaR}$ is now a Renal Association initiative coordinated by the UKRR that collates data of recruited patients with certain rare kidney diseases. $\mathrm{RaDaR}$ provides clinicians with an invaluable resource to accelerate research and presents patients with opportunities to participate in research.

\section{Information governance - the care of patient data}

The UKRR continues to receive support under section 251 of the NHS Act (2006) to collect data without individual patient consent. This helps to ensure the robustness and validity of analyses. The fair processing of patient data remains a key principle of the General Data Protection Regulation (2016) which is soon to replace the Data Protection Act (1998). This requires organisations to be clear and open with individuals about how their information is used. The UKRR publishes this information on the UKRR website and in patient information leaflets and posters, which are distributed to all renal centres. Each year the UKRR completes NHS Digital's Information Governance Toolkit and for the 2017/2018 assessment period achieved a score of $94 \%$ (subject to audit) against the 'satisfactory' standard of $80 \%$. Further information on information governance is available on the UKRR website.

\section{Audit}

\section{Annual report}

The UKRR collects data primarily for benchmarking each of the UK's 84 renal centres against Renal Association audit standards (https://renal.org/guidelines/). Each year the UKRR publishes an annual report comprising chapters that each focus on different aspects of renal care and patient outcomes. Centre comparisons, attainment of Renal Association audit standards, national averages and long term trends are all presented. Each year, new or revised chapters are usually added that focus on novel ways of analysing and presenting the data. To improve the timeliness of publication of this report of 2016 data, no new chapters are presented. Conversely, for next year's report three revamped chapters are planned, namely comorbidity, diabetes and ethnicity. A novel authorship approach will be taken to the ethnicity chapter, involving several members of the UKRR patient council in deciding the scope and writing of this chapter.

\section{Data completeness}

Data completeness of audit standards varied between renal centres as summarised in appendix 1 of this chapter, with more details provided in individual chapters. While poor completeness may reflect a failure to accurately record patient data, other contributing factors include the incompatibility of local renal IT systems and the loss of data during the transfer and validation processes on account of coding issues. Cambridge renal centre (Addenbrooke's Hospital) was unable to submit any patient level data for 2015 and 2016 prior to the UKRR closing the database and only provided summary numbers by treatment modality for incident and prevalent patients in 2015 and 2016. The UKRR is working closely with the renal team, the chief executive of Cambridge University NHS Foundation Trust and NHS England to address this and files are now being received again. Data completeness is likely to improve with the development of the UKRDC and increasing uptake of the latest UKRR dataset. The dataset has evolved and expanded over time in response to audit 
guidelines, with an understandable variable lag in the ability of local renal IT systems to respond to those changes.

The UKRR started collecting data on CKD4/5 patients registered in renal centres in 2016 and a few renal centres are returning these data as part of their quarterly extract. These data will be analysed and reported on in the next annual report. The AKI master patient index, established as part of the NHS England safety alert, is progressing well with almost $90 \%$ of laboratories in England submitting data (see sections Improvements and innovations in patient care and AKI national program below for more details).

Crucially, comorbidity data completeness at the start of RRT remained poor, with more than half (33/62) of the adult renal centres in England, Wales and Northern Ireland having lower than $75 \%$ completeness for comorbidity data. Thirteen renal centres submitted comorbidity data on fewer than $10 \%$ of their incident patients. Two renal centres (London Guy's Hospital and St Thomas' Hospital, Lister Hospital) returned comorbidity data for incident patients in the new format as described in version 4.2 of the dataset, but the date associated with the comorbidity was not completed and comorbidities at start of RRT could not be ascertained. All of this makes it impossible for the UKRR to adjust survival analyses for case mix, something that is particularly relevant to outlying centres [1]. NHS Digital recently approved the linkage of the main UKRR database to the Hospital Episode Statistics (HES) and Office of National Statistics databases. This has the potential to enhance UKRR data in a number of ways, by:

- Enabling adjustment for case-mix in centre survival comparisons.

- Providing information about differences in rates of hospital admission between renal centres.

- Making it possible to study equity of access to other non-renal services, such as cardiology, stroke and orthopaedic.

- Transforming the AKI database from a master patient index of all cases of AKI in primary and secondary care into one with information about admissions to hospital, reasons for admission to hospital, admissions to intensive care units and mortality.

\section{How to interpret centre-specific analyses and outlying} centres

The UKRR continues to advise caution in the interpretation of the comparisons of centre-specific attainment of clinical audit measures provided in this report. As in previous reports, the UKRR does not test for 'significant difference' between centres and arbitrary 95\% and 99\% confidence intervals are created from the data to show compliance with an audit standard. For many of these analyses no adjustment can be made for the range of factors known to influence the measured variable. In the future, through obtaining more complete comorbidity data via the HES data linkage, as well as using CKD data to understand centre differences in the transition of patients onto both RRT and conservative non-dialytic pathways, centre comparisons will become more meaningful.

Despite these shortcomings, for a number of years deanonymised centre specific reports on survival of RRT patients have been published in the annual report. The Francis [2] and Keogh [3] enquiries and the ongoing Care Quality Commission inspections of patient care and outcomes at a number of hospital trusts highlight the ongoing need for such transparency. This year (2016 data) four centres had to be contacted because of lower than expected survival in patients starting dialysis.

The UKRR has no statutory powers. However, because the UKRR provides centre-specific de-anonymised analyses of important clinical outcomes, including survival, it is important to define how the UKRR responds to apparent under-performance. The UKRR senior management team communicates survival outlier status with the renal centres prior to publication. Centres are asked to report their outlying status internally at trust level and to follow up with robust mortality and morbidity meetings. They are also asked to provide evidence that the clinical governance department and chief executive of the trust housing the service have been informed. In the event that no such evidence is provided, the chief executive officer or medical director of the UKRR inform the president of the Renal Association, who then takes action to ensure that the findings are properly investigated.

\section{Research}

The UKRR research team welcomes contact from renal clinicians and other researchers wishing to access UKRR data and/or collaborate with the UKRR on research projects and grant applications. Data can be released in one of two formats: 
- Aggregated, e.g. tables and figures and results of statistical analyses.

- Individual level (anonymised).

In line with the UKRR's ongoing section 251 permission, in April 2017, formal application processes were introduced to access data. Applications to access aggregated data can be submitted at any time during the year and a decision is made by the UKRR medical director and head statistician. In contrast, applications to access individual level data must be received before a quarterly deadline, be assessed for risk of re-identification, be approved for external review by two external experts and then discussed at a quarterly meeting of the UKRR's Research Methods Study Group, where a decision on whether to release the data is made. A data sharing agreement is then drawn up between the UKRR and the data recipient prior to delivery of the data. More information is available on the UKRR website (https://www.renalreg.org/about-us/working-with-us/).
The majority of applications to access individual level data are either retrospective or prospective cohort analyses, although the UKRR does also provide large data sets for epidemiological and exploratory analyses and efficient outcome data for clinical trials. The UKRR is currently leading two National Institute for Health Research-Health Technology Assessment funded randomised controlled trials: (i) the Prepare for Kidney Care study randomises older comorbid patients approaching ESRD to either prepare for responsive management or prepare for dialysis [4]; and (ii) the Highvolume Haemodiafiltration vs. High-flux Haemodialysis Registry Trial randomises patients to two different types of dialysis [5].

Applications to access UKRR data that were approved in 2017-2018 are listed in table 1. Grant funding received by the UKRR is detailed in table 2 . Recent publications by UKRR authors are listed in appendix 2 of this chapter.

Table 1. Applications to access UKRR data that were approved in $2017-2018$, listed alphabetically by applicant

\begin{tabular}{|c|c|c|}
\hline Applicant & Data type & Title/description of application \\
\hline $\begin{array}{l}\text { David Bagguley, NHS England Specialised } \\
\text { Commissioning Team, Yorkshire and Humber }\end{array}$ & Aggregate & Local provision of RRT services \\
\hline Jyoti Baharani, Birmingham Heartlands Hospital & Aggregate & Local incidence and prevalence of peritoneal dialysis \\
\hline Michael Barrowman, University of Manchester & Anonymised & Multi-state clinical prediction models in RRT \\
\hline Aric Bendorf, University of Sydney, Australia & Aggregate & International transplant wait-listing practices \\
\hline Kate Birnie, University of Bristol & Anonymised & $\begin{array}{l}\text { An instrumental variable analysis for investigating } \\
\text { erythropoietin therapy for treating anaemia among } \\
\text { haemodialysis patients }\end{array}$ \\
\hline Ben Bray, London Borough of Redbridge & Aggregate & Local incidence of patients with diabetic nephropathy \\
\hline $\begin{array}{l}\text { Sheena Dungey, Kent Surrey Sussex Academic } \\
\text { Health Science Network }\end{array}$ & Aggregate & Local AKI data for quality improvement \\
\hline Katie Fielding, Royal Derby Hospital & Aggregate & Dialysis access and needling data \\
\hline $\begin{array}{l}\text { Hugh Gallagher, Epsom and St Helier University } \\
\text { Hospitals }\end{array}$ & Aggregate & $\begin{array}{l}\text { Identifying and monitoring people at greatest risk of } \\
\text { progressive CKD (ASSIST-CKD) - quality improvement }\end{array}$ \\
\hline George Greenhall, Barts Health NHS Trust & Anonymised & $\begin{array}{l}\text { Clinical epidemiology of renal transplantation for rare renal } \\
\text { diseases in the UK }\end{array}$ \\
\hline Alex Hamilton, UKRR and University of Bristol & Anonymised & $\begin{array}{l}\text { Risk factors for decline and loss of kidney transplant function } \\
\text { among UK children and young adults }\end{array}$ \\
\hline Kitty Jager, ERA-EDTA & Anonymised & $\begin{array}{l}\text { Changes in clinical parameters related to the transition from } \\
\text { dialysis to kidney transplantation }\end{array}$ \\
\hline Kitty Jager, ERA-EDTA & Anonymised & $\begin{array}{l}\text { Outcome of paediatric kidney transplantation in Europe - } \\
\text { results from the ESPN/ERA-EDTA Registry }\end{array}$ \\
\hline Kitty Jager, ERA-EDTA & Anonymised & Recovery of renal function in the ERA-EDTA Registry \\
\hline Matthew Katz, Department of Health & Aggregate & $\begin{array}{l}\text { Identifying and monitoring people at greatest risk of } \\
\text { progressive CKD (ASSIST-CKD) - trial and cost-saving } \\
\text { analysis for NHS Blood and Transplant on renal transplants }\end{array}$ \\
\hline
\end{tabular}


Table 1. Continued

\begin{tabular}{|c|c|c|}
\hline Applicant & Data type & Title/description of application \\
\hline $\begin{array}{l}\text { Kate Lovibond, National Clinical Guideline Centre, } \\
\text { Royal College of Physicians }\end{array}$ & Aggregate & $\begin{array}{l}\text { To develop National Institute for Health and Care Excellence } \\
\text { (NICE) RRT guideline }\end{array}$ \\
\hline $\begin{array}{l}\text { Stephanie MacNeill, UKRR and University of } \\
\text { Bristol }\end{array}$ & Anonymised & Benefits of transplant \\
\hline Lucy Plumb, UKRR and University of Bristol & Anonymised & $\begin{array}{l}\text { BAPN/UKRR paediatric RRT mortality audit: what is the } \\
\text { completeness and accuracy of UKRR data for causes of death? }\end{array}$ \\
\hline Lucy Plumb, UKRR and University of Bristol & Anonymised & $\begin{array}{l}\text { Does socioeconomic status or geographic location play a role } \\
\text { in access to nephrology services for UK children with CKD? }\end{array}$ \\
\hline Rishi Pruthi, Royal Free Hospital & Aggregate & Planning of CKD services in North Central London \\
\hline Rhodri Pyart, UKRR & Anonymised & $\begin{array}{l}\text { The management and survival of patients with failing and } \\
\text { failed renal allografts within the UK }\end{array}$ \\
\hline Joe Sheehan, University of Kent & Aggregate & Patient incidence dialysis data for a dialysis transport study \\
\hline Manish Sinha, Evelina London Children’s Hospital & Aggregate & Information on children who start RRT on haemodialysis \\
\hline
\end{tabular}

AKI - acute kidney injury; BAPN - British Association for Paediatric Nephrology; CKD - chronic kidney disease; ERA-EDTA - European Renal Association-European Dialysis and Transplant Association; ESPN - European Society for Paediatric Nephrology; RRT - renal replacement therapy

Table 2. Grant transactions 1 January 2017 to 31 December 2017

\begin{tabular}{|c|c|}
\hline Description & Value \\
\hline Cambridge - Access to Transplantation and Transplant Outcome Measures (ATTOM) & $£ 2,039$ \\
\hline Intensive Care National Audit and Research Centre (ICNARC) - risk modelling study & $£ 7,209$ \\
\hline $\begin{array}{l}\text { Keele University - Bioimpedance guided fluid management in dialysis patients - the BioImpedance Spectroscopy } \\
\text { to Maintain Renal Output (BISTRO) trial }\end{array}$ & $£ 11,799$ \\
\hline Kidney Research UK - the National Unified Renal Translational Research Enterprise (NURTuRE) & 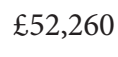 \\
\hline North Bristol NHS Trust - Prepare for Kidney Care trial & $£ 1,443$ \\
\hline UK and Ireland Vasculitis Rare Disease Group - anti-neutrophil cytoplasm antibodies vasculitis workshop & $£ 5,360$ \\
\hline University of Leicester, International RaDaR work completed by UKRR & 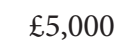 \\
\hline
\end{tabular}

RaDaR - National Registry of Rare Kidney Diseases

\section{Improvements and innovations in patient care}

A major component of UKRR work is delivering changes in practice that improve the care of people with, or at risk of, kidney disease. This work falls under the banner of the UKRR's Think Kidneys brand (https://www.thinkkidneys.nhs.uk/). All three Think Kidneys programmes have made significant progress over the past 12 months.

\section{AKI national programme}

This is a national NHS campaign to improve the care of people at risk of, or with, AKI. The programme was a partnership between the UKRR and NHS England, and then latterly, NHS Improvement. The programme has produced a wide range of guidance and information for people working in all healthcare sectors to help with the prevention, detection, management and treatment of AKI. Examples include education packages about AKI for a range of health professionals, updated sickday rules and specific resources for patients and carers. The first programme of work concluded in March 2017 and the second phase is now underway. Think Kidneys and the wider UKRR team continue to develop resources on the Think Kidneys website, lead improvements in care and report on the impact of AKI across England.

A key success of the programme has been the establishment of a master patient index of people who have 
had a blood test triggered AKI alert across England. Almost 90\% of laboratories in England (143/160) now submit AKI data from primary and secondary care to the UKRR. This has enabled the UKRR to report quarterly AKI rates at a clinical commissioning group level since October 2017. The next steps for the master patient index include linkage to HES to allow hospital specific reporting of AKI rates. Further details on the master patient index and how it is being used can be accessed on the Think Kidneys website.

\section{Patient Measures}

The Patient Measures programme supports a personcentred approach to care where people are supported to build their skills, knowledge and confidence to better manage and make decisions about their own health to improve their quality of life.

This programme is a collaboration between the UKRR and NHS England and follows on from the work of the Transforming Participation in Chronic Kidney Disease (TP-CKD) programme which ended in December 2017. The TP-CKD programme aimed to establish the feasibility of the UKRR introducing and routinely collecting from kidney patients a series of person-centred measures such as symptom burden, quality of life and the ability to self-manage. Having successfully piloted the collection of these data from patients in 14 renal centres, the programme is continuing to collect patient reported measurements as well as testing interventions that might have a positive impact on an individual's outcome.

A development of this programme has been the introduction of an annual Patient Reported Experience Measures (PREM) survey. This is a joint collaboration between the UKRR and Kidney Care UK. This collaboration has enabled the expansion of this survey beyond the original programme and now every adult renal centre in England and Wales is invited to take part. The PREM has run annually since the first pilot in 2016, with last year's collection resulting in over 11,000 completed PREM surveys. The survey has been validated and a national report on the results is published each year. For further information see https://www.renalreg.org/projects/prem.

\section{Kidney Quality Improvement Partnership}

The Kidney Quality Improvement Partnership (KQuIP) is a dynamic network of kidney health professionals, patients and carers who are committed to developing, supporting and sharing quality improvement (QI) in kidney services to enhance outcomes and quality of life for patients with kidney disease. KQuIP supports healthcare professionals, renal centres, renal networks and commissioners across the UK to achieve the highest quality of care for patients.

Since its launch in 2016, KQuIP has established a clear structure and achieved major engagement within the UK renal community. KQuIP has set up three active workstreams, regional QI days and three robust national priority QI projects. In addition, a highly acclaimed leadership training course for clinical directors has been established, which will be extended to the multi professional team and could include patients.

KQuIP's three national priority projects identified by the renal community are:

- Transplant First: improving access to pre-dialysis transplant listing and kidney transplantation.

- Home Therapies: improving access to home dialysis therapies.

- Managing Access by Generating Improvements in Cannulation (MAGIC): improving arteriovenous fistula rates by improving needling techniques.

KQuIP has made excellent progress over the past year, collaborating with Kidney Care UK funded regional project managers, to deliver four successful QI days covering a population of almost 20 million people. KQuIP is now working with each of these four regions to deliver one of the three national QI projects over the next year. There have been expressions of interest for future KQuIP regional days, including a paediatric network day and links with the home countries. KQuIP are working to deliver these over 2018/19.

KQuIP have produced a central repository of resources called the KQuIP Hub (https://www.thinkkidneys.nhs. $\mathrm{uk} / \mathrm{kquip} / \mathrm{kquip}-\mathrm{hub} /$ ). This is a growing resource to make QI accessible to clinicians and multidisciplinary team members, as well as patients. Material includes QI tools, sharing of best practice, case studies, abstracts from UK Kidney Week and other major renal events. The feedback on the Hub has been very encouraging and content fit for the renal community will continue to be developed.

The Association of Renal Industries has provided funding to develop a renal e-Learning platform that will be free for all medical healthcare professionals and patients to access. This is a very exciting development that will be owned by the renal community and further input will be requested as it progresses. A number of modules have already been developed and these will be available shortly. 
Moving forward, KQuIP has developed an in depth strategic QI delivery plan as well as a QI training plan for regional delivery of the national priority QI projects. Alongside the leadership training course, the training plan will focus on specific QI skills and sustainability to enable regions to embed QI on a day to day basis. KQuIP will link to the Getting It Right First Time (GIRFT) and regional Right Care programmes and other programmes planned by the Renal Association.

\section{Clinical informatics}

The UKRDC is a new process for collecting data for kidney patients, whereby data will flow into a central data repository and flow onto other databases including $\mathrm{RaDaR}$ and PV. Advantages of the UKRDC include real time data access and processing, standardised processing and nomenclature, and the ability to link quickly with other databases.

The implementation of the UKRDC requires IT developments, such as adopting standard terms using SNOMED CT and LOINC; adopting standard methods for labelling and formatting data via the creation of a data model and standard messaging system; and developing two way communications between all participants including patients via PV.

During testing over the past 12 months it became apparent that the current implementation of the UKRDC was hindering development and had a number of shortcomings, most notably excessive storage requirements. A decision was therefore taken to rebuild the UKRDC around a Mirth server, this being the most cost effective and simple way to reduce storage requirements and increase the speed of development of new data paths.

Currently, one pilot renal centre has successfully started sending UKRDC schema based files through the UKRDC and by the end of 2018 full quarterly returns will be returned via this route.

The new system is being developed with the view to providing better feedback to renal centres on problems with files and rejections, allowing corrections to be made to export routines/patient data, which will overcome some of the shortcomings in the current system.

Besides the live server there is now a staging site available with staging versions of $\mathrm{RaDaR}$ and $\mathrm{PV}$. This new server configuration allows renal centres/suppliers to use the system as a test bed for development of the new UKRDC schema feeds (https://github.com/renalreg/ukrdc). Renal centres or suppliers interested in being given access to the system should contact the UKRR.

New pathways are in development this year to allow patients to enter surveys via PV and the survey results to be sent back for display in clinical systems against the patient record. This combined with the new mobile app for PV could provide new tools to gather more patient entered data.

The concept of the UKRDC has been proven and data are flowing through the UKRDC in both directions. Work with pilot sites is progressing, but the success of the UKRDC depends on support and commitment from renal centres and the renal community.

\section{Summary}

Medicine is evolving rapidly, as is the technology that clinicians and patients have become accustomed to using in their day-to-day lives. The challenge is to process, analyse and report data as quickly as possible to ensure outputs are clinically meaningful and to help engage patients in the ongoing management of their kidney conditions. The progress of the UKRDC and evolution of PV, as well as the great work of the Think Kidneys programmes, exemplify how the renal community can remain at the forefront of patient-centred care. Expanding data collection to AKI and CKD, as well as external data linkages, particularly to HES, will allow more detailed analyses and make inter-centre comparisons much more transparent.

This is all being done against an evolving information security backdrop, including how the General Data Protection Regulation will be written into UK Data Protection Act law. While there remains some uncertainty as to the exact implications of the new law in the UK, early signs are that it could make data sharing for public benefit easier, whilst maintaining high standards of guardianship of personal data. For the UKRR, after a number of years of backroom development, exciting opportunities are likely to emerge, including monitoring patient quality of life and real-time interrogation of national data for local audit and quality improvement. It is only with such developments that the UKRR can justify its ongoing privileged access to the data and work with the community to drive forward improvements in people-centred kidney care in the UK.

Conflicts of interest: the authors declare no conflicts of interest 


\section{References}

1 Fotheringham J, Jacques RM, Fogarty D, Tomson CR, El Nahas M, Campbell MJ. Variation in centre-specific survival in patients starting renal replacement therapy in England is explained by enhanced comorbidity information from hospitalization data. Nephrol Dial Transplant 2014; 29(2): 422-30

2 Keogh B. Review into the quality of care and treatment provided by 14 hospital trusts in England: overview report. 2013. https://www.nhs.uk/ NHSEngland/bruce-keogh-review/Documents/outcomes/keogh-reviewfinal-report.pdf

3 Francis R. Report of the Mid Staffordshire NHS Foundation Trust Public Inquiry; Executive summary. The Stationery Office, London. 2013. https:// www.gov.uk/government/uploads/system/uploads/attachment_data/file/ 279124/0947.pdf

4 Caskey F. Prepare for Kidney Care: a randomised controlled trial of preparing for responsive management versus preparing for renal dialysis in advanced kidney disease. https://www.journalslibrary.nihr.ac.uk/programmes/hta/155739/\#/

5 Caskey F. The High-volume Haemodiafiltration vs. High-flux Haemodialysis Registry Trial (H4RT). https://www.journalslibrary.nihr.ac.uk/programmes/hta/158052/\#/ 


\section{Appendix 1}

\section{Percentage completeness}

Table 3. Percentage completeness of data returns for ethnicity, primary renal diagnosis, date first seen by a nephrologist, comorbidity at start of RRT (incident patients 2016) and cause of death (for deaths in 2016 amongst prevalent patients on 31/12/15), ordered by 2016 average completeness

\begin{tabular}{|c|c|c|c|c|c|c|c|}
\hline Centre & Ethnicity & $\begin{array}{l}\text { Primary } \\
\text { diagnosis }\end{array}$ & $\begin{array}{c}\text { Date } \\
\text { first seen }\end{array}$ & Comorbidity & $\begin{array}{l}\text { Cause } \\
\text { of death }\end{array}$ & $\begin{array}{c}\text { Average } \\
\text { completeness }\end{array}$ & Country \\
\hline Antrim & 100.0 & 100.0 & 100.0 & 100.0 & 100.0 & 100.0 & $\mathrm{~N}$ Ireland \\
\hline L Kings & 100.0 & 100.0 & 99.3 & 98.7 & 98.1 & 99.2 & England \\
\hline Nottm & 99.2 & 100.0 & 100.0 & 100.0 & 96.1 & 99.1 & England \\
\hline West NI & 97.1 & 100.0 & 97.1 & 100.0 & 100.0 & 98.9 & N Ireland \\
\hline Bradfd & 98.8 & 100.0 & 100.0 & 97.7 & 95.8 & 98.5 & England \\
\hline Ulster & 100.0 & 100.0 & 100.0 & 90.0 & 100.0 & 98.0 & N Ireland \\
\hline B Heart & 100.0 & 100.0 & 100.0 & 94.1 & 93.3 & 97.5 & England \\
\hline Cardff & 96.3 & 100.0 & 99.4 & 97.5 & 93.5 & 97.3 & Wales \\
\hline Swanse & 100.0 & 99.2 & 100.0 & 93.6 & 93.9 & 97.3 & Wales \\
\hline Newc & 100.0 & 100.0 & 100.0 & 94.0 & 92.5 & 97.3 & England \\
\hline Leeds & 99.4 & 100.0 & $98.6^{\mathrm{b}}$ & 99.4 & 88.8 & 97.2 & England \\
\hline Dorset & 98.6 & 100.0 & 97.1 & 95.7 & 93.2 & 96.9 & England \\
\hline Derby & 98.8 & 98.8 & 100.0 & 91.9 & 93.4 & 96.6 & England \\
\hline Dudley & 100.0 & 98.1 & 100.0 & 93.9 & 90.5 & 96.5 & England \\
\hline Wrexm & 93.9 & 93.9 & 100.0 & 93.6 & 100.0 & 96.3 & Wales \\
\hline York & 93.1 & 100.0 & 100.0 & 93.0 & 95.2 & 96.3 & England \\
\hline Middlbr & 98.0 & 100.0 & 100.0 & 99.0 & 83.0 & 96.0 & England \\
\hline Bangor & 88.0 & 92.0 & 100.0 & 100.0 & 100.0 & 96.0 & Wales \\
\hline Newry & 100.0 & 100.0 & 100.0 & 96.0 & 80.0 & 95.2 & $\mathrm{~N}$ Ireland \\
\hline Stoke & 90.7 & 99.1 & 98.1 & 96.3 & 91.8 & 95.2 & England \\
\hline Redng & 84.4 & 99.0 & 100.0 & 95.8 & 95.9 & 95.0 & England \\
\hline Basldn & 95.0 & 95.0 & 95.0 & 85.0 & 91.4 & 92.3 & England \\
\hline Sund & 100.0 & 100.0 & 98.9 & 68.1 & 91.5 & 91.7 & England \\
\hline Wolve & 100.0 & 100.0 & 95.3 & 100.0 & 62.0 & 91.5 & England \\
\hline Exeter & 98.6 & 98.6 & 97.2 & 70.9 & 89.1 & 90.9 & England \\
\hline Norwch & 97.9 & 100.0 & $96.3^{\mathrm{b}}$ & 99.0 & 61.2 & 90.9 & England \\
\hline Wirral & 97.1 & 100.0 & 97.1 & 100.0 & 59.5 & 90.7 & England \\
\hline Hull & 97.8 & 96.8 & 100.0 & 93.4 & 60.0 & 89.6 & England \\
\hline Plymth & 98.4 & 92.1 & 100.0 & 60.7 & 92.0 & 88.6 & England \\
\hline Sthend & 100.0 & 95.7 & 95.7 & 57.5 & 86.0 & 87.0 & England \\
\hline Donc & 100.0 & 98.4 & 98.4 & 54.1 & 81.8 & 86.5 & England \\
\hline Glouc & 98.5 & 98.5 & 93.9 & 44.6 & 78.6 & 82.8 & England \\
\hline Chelms & 100.0 & 94.3 & 90.6 & 34.7 & 92.7 & 82.5 & England \\
\hline Oxford & 79.8 & 87.6 & 99.5 & 67.9 & 75.4 & 82.0 & England \\
\hline Colchr & 96.7 & $87.3^{\mathrm{a}}$ & 46.7 & 100.0 & 78.3 & 81.8 & England \\
\hline Shrew & 96.6 & 100.0 & 100.0 & 98.3 & 8.3 & 80.6 & England \\
\hline Truro & 100.0 & 100.0 & 100.0 & 2.0 & 100.0 & 80.4 & England \\
\hline L West & 100.0 & 100.0 & 99.5 & 1.0 & 98.9 & 79.9 & England \\
\hline $\mathrm{B} \mathrm{QEH}$ & 96.2 & 98.7 & 100.0 & 86.6 & 4.2 & 77.1 & England \\
\hline Carlis & 97.1 & 57.3 & 94.3 & 48.6 & 85.3 & 76.5 & England \\
\hline Prestn & 100.0 & 98.5 & 97.0 & 3.8 & 83.2 & 76.5 & England \\
\hline Brightn & 89.3 & 100.0 & 98.0 & 1.3 & 91.9 & 76.1 & England \\
\hline L Guys & 94.7 & 91.1 & 94.7 & 0.0 & 90.1 & 74.1 & England \\
\hline Liv Ain & 98.1 & 100.0 & 98.1 & 62.3 & 10.0 & 73.7 & England \\
\hline Kent & 97.9 & 61.2 & 100.0 & 2.1 & 100.0 & 72.2 & England \\
\hline Clwyd & 81.3 & 62.5 & 81.3 & 43.8 & 92.3 & 72.2 & Wales \\
\hline Bristol & 80.6 & 83.9 & 73.6 & 54.2 & 65.3 & 71.5 & England \\
\hline Sheff & 97.4 & 92.7 & 99.3 & 55.0 & 0.0 & 68.9 & England \\
\hline Belfast & 82.1 & 90.5 & 87.4 & 41.1 & 43.2 & 68.8 & N Ireland \\
\hline
\end{tabular}

Introduction to the 20th Annual Report

Nephron 2018;139(suppl1):1-12 
Table 3. Continued

\begin{tabular}{|c|c|c|c|c|c|c|c|}
\hline Centre & Ethnicity & $\begin{array}{l}\text { Primary } \\
\text { diagnosis }\end{array}$ & $\begin{array}{c}\text { Date } \\
\text { first seen }\end{array}$ & Comorbidity & $\begin{array}{l}\text { Cause } \\
\text { of death }\end{array}$ & $\begin{array}{c}\text { Average } \\
\text { completeness }\end{array}$ & Country \\
\hline Leic & 91.0 & 76.5 & 98.8 & 0.3 & 50.0 & 63.3 & England \\
\hline M RI & 95.9 & 89.0 & 94.5 & 34.4 & 1.4 & 63.0 & England \\
\hline L Rfree & 95.0 & 91.6 & 96.6 & 3.8 & 16.0 & 60.6 & England \\
\hline Stevng & 85.5 & 90.9 & 99.4 & 1.8 & 7.9 & 57.1 & England \\
\hline Covnt & 96.9 & 64.2 & 96.1 & 7.9 & 1.9 & 53.4 & England \\
\hline L Barts & 99.7 & 80.1 & 1.4 & 36.7 & 42.4 & 52.0 & England \\
\hline Liv Roy & 97.3 & 33.3 & 99.1 & 12.6 & 4.5 & 49.4 & England \\
\hline Ports & 84.3 & 46.6 & 41.4 & 12.0 & 24.0 & 41.6 & England \\
\hline Salford & 96.8 & 88.3 & 5.9 & 0.0 & 0.9 & 38.4 & England \\
\hline L St.G & 85.1 & 37.2 & $15.5^{\mathrm{b}}$ & 21.5 & 26.8 & 37.2 & England \\
\hline Ipswi & 92.9 & 50.0 & 23.8 & 0.0 & 5.9 & 34.5 & England \\
\hline Carsh & 91.1 & 24.8 & 41.5 & 2.9 & 10.8 & 34.2 & England \\
\hline Camb & & & & & & & England \\
\hline Abrdn & & 100.0 & & & 81.8 & & Scotland \\
\hline Airdrie & & 100.0 & & & 92.2 & & Scotland \\
\hline D \& Gall & & 100.0 & & & 69.2 & & Scotland \\
\hline Dundee & & 100.0 & & & 98.0 & & Scotland \\
\hline Edinb & & 100.0 & & & 100.0 & & Scotland \\
\hline Glasgw & & 100.0 & & & 92.2 & & Scotland \\
\hline Inverns & & 100.0 & & & 85.7 & & Scotland \\
\hline Klmarnk & & 100.0 & & & 100.0 & & Scotland \\
\hline Krkcldy & & 62.5 & & & 80.5 & & Scotland \\
\hline
\end{tabular}

${ }^{a}$ Data from these centres included a high proportion of patients whose primary renal diagnosis was 'uncertain'. In some cases, this appears to have been because software in these centres was defaulting missing values to 'uncertain'. The value given for the completeness has been reduced in proportion to the amount by which the percentage of non-missing diagnoses being 'uncertain' exceeded $40 \%$

${ }^{b}$ More than $10 \%$ of patients reported as starting RRT on the same date as first presentation, the percentage completeness shown excludes the amount by which this exceeded $10 \%$ 


\section{Appendix 2}

\section{Original research by UKRR staff involving UKRR data}

1 Performance of an easy-to-use prediction model for renal patient survival: an external validation study using data from the ERA-EDTA Registry. Hemke AC, Heemskerk MBA, van Diepen M, Kramer A, de Meester J, Heaf JG, Abad Diez JM, Torres Guinea M, Finne P, Brunet P, Vikse BE, Caskey FJ, Traynor JP, Massy ZA, Couchoud C, Groothoff JW, Nordio M, Jager KJ, Dekker FW, Hoitsma AJ. Nephrol Dial Transplant. 2018 Jan 16. doi: 10.1093/ndt/gfx348.

2 The European Renal Association - European Dialysis and Transplant Association (ERA-EDTA) Registry Annual Report 2015: a summary. Kramer A, Pippias M, Noordzij M, Stel VS, Afentakis N, Ambühl PM, Andrusev AM, Fuster EA, Arribas Monzón FE, Åsberg A, Barbullushi M, Bonthuis M, Caskey FJ, Castro de la Nuez P, Cernevskis H, des Grottes JM, Garneata L, Golan E, Hemmelder MH, Ioannou K, Jarraya F, Kolesnyk M, Komissarov K, Lassalle M, Macario F, Mahillo-Duran B, Martín de Francisco AL, Palsson R, Pechter Ü, Resic H, Rutkowski B, Santiuste de Pablos C, Seyahi N, Simic Ogrizovic S, Slon Roblero MF, Spustova V, Stojceva-Taneva O, Traynor J, Massy ZA, Jager KJ. Clin Kidney J. 2018 Feb;11(1):108-122. doi: 10.1093/ckj/sfx149.

3 Kidney transplant outcomes from older deceased donors: a paired kidney analysis by the European Renal Association-European Dialysis and Transplant Association Registry. Pippias M, Jager KJ, Caskey F, Casula A, Erlandsson H, Finne P, Heaf J, Heinze G, Hoitsma A, Kramar R, Lempinen M, Magaz A, Midtvedt K, Mumford LL, Pascual J, Prütz KG, Sørensen SS, Traynor JP, Massy ZA, Ravanan R, Stel VS. Transpl Int. 2017 Dec 5. doi: $10.1111 /$ tri.13103.

4 The European Renal Association-European Dialysis and Transplant Association Registry Annual Report 2014: a summary. Pippias M, Kramer A, Noordzij M, Afentakis N, Alonso de la Torre R, Ambühl PM, Aparicio Madre MI, Arribas Monzón F, Åsberg A, Bonthuis M, Bouzas Caamaño E, Bubic I, Caskey FJ, Castro de la Nuez P, Cernevskis H, de Los Ángeles Garcia Bazaga M, des Grottes JM, Fernández González R, Ferrer-Alamar M, Finne P, Garneata L, Golan E, Heaf JG, Hemmelder MH, Idrizi A, Ioannou K, Jarraya F, Kantaria N, Kolesnyk M, Kramar R, Lassalle M, Lezaic VV, Lopot F, Macario F, Magaz Á, Martín de Francisco AL, Martín Escobar E, Martínez Castelao A, Metcalfe W, Moreno Alia I, Nordio M, Ots-Rosenberg M, Palsson R, Ratkovic M, Resic H, Rutkowski B, Santiuste de Pablos C, Seyahi N, Fernanda Slon Roblero M, Spustova V, Stas KJF, Stendahl ME, Stojceva-Taneva O, Vazelov E, Ziginskiene E, Massy Z, Jager KJ, Stel VS. Clin Kidney J. 2017 Apr;10(2):154-169. doi: 10.1093/ $\mathrm{ckj} / \mathrm{sfw} 135$.

5 Access to kidney transplantation in European adults aged 75-84 years and related outcomes: an analysis of the European Renal Association-European Dialysis and Transplant Association Registry. Pippias M, Stel VS, Kramer A, Abad Diez JM, Aresté-Fosalba N, Ayav C, Buturovic J, Caskey FJ, Collart F, Couchoud C, De Meester J, Heaf JG, Helanterä I, Hemmelder MH, Kostopoulou M, Noordzij M, Pascual J, Palsson R, Reisaeter AV, Traynor JP, Massy Z, Jager KJ. Transpl Int. 2018 May;31(5):540-553. doi: $10.1111 /$ tri.13125.

\section{Original research by UKRR staff involving other data}

1 Cinacalcet use and the risk of cardiovascular events, fractures and mortality in chronic kidney disease patients with secondary hyperparathyroidism. Evans M, Methven S, Gasparini A, Barany P, Birnie K, MacNeill S, May MT, Caskey FJ, Carrero JJ. Sci Rep. 2018 Feb 1;8(1):2103. doi: 10.1038/s41598-018-20552-5.

2 Sociodemographic, Psychologic Health, and Lifestyle Outcomes in Young Adults on Renal Replacement Therapy. Hamilton AJ, Clissold RL, Inward
CD, Caskey FJ, Ben-Shlomo Y. Clin J Am Soc Nephrol. 2017 Dec 7;12(12):1951-1961. doi: 10.2215/CJN.04760517.

3 Do stop me now: gastric acid-reducing drugs following renal transplantation. Held I, Pyart R. J Kidney Care. 2018 3:1:6-13. doi: 10.12968/ jokc.2018.3.1.6

4 End-of-life care for people with chronic kidney disease: cause of death, place of death and hospital costs. Kerr M, Matthews B, Medcalf JF, O’Donoghue D. Nephrol Dial Transplant. 2017 Sep 1;32(9):1504-1509. doi: $10.1093 / \mathrm{ndt} / \mathrm{gfw} 098$.

5 Attainment of guideline targets in EURODOPPS haemodialysis patients: are differences related to a country's healthcare expenditure and nephrologist workforce? Liabeuf S, Van Stralen KJ, Caskey F, Tentori F, Pisoni RL, Sajjad A, Jager KJ, Massy ZA. Nephrol Dial Transplant. 2017 Oct 1;32(10):1737-1749. doi: 10.1093/ndt/gfw409.

6 Paediatric anti-neutrophil cytoplasmic antibody (ANCA)-associated vasculitis: an update on renal management. Plumb LA, Oni L, Marks SD, Tullus K. Pediatr Nephrol. 2018 Jan;33(1):25-39. doi: 10.1007/s00467-0163559-2.

7 Prevalence and Risk of Protein-Energy Wasting Assessed by Subjective Global Assessment in Older Adults With Advanced Chronic Kidney Disease: Results From the EQUAL Study. Windahl K, Faxén Irving G, Almquist T, Lidén MK, van de Luijtgaarden M, Chesnaye NC, Voskamp P, Stenvinkel P, Klinger M, Szymczak M, Torino C, Postorini M, Drechsler C, Caskey FJ, Wanner C, Dekker FW, Jager KJ, Evans M. J Ren Nutr. 2018 May;28(3):165-174. doi: 10.1053/j.jrn.2017.11.002.

\section{Editorials, reviews, commentaries and methods papers by UKRR staff}

1 KDIGO Controversies Conference on Challenges in the Conduct of Clinical Trials in Nephrology Conference Participants. Challenges in conducting clinical trials in nephrology: conclusions from a Kidney DiseaseImproving Global Outcomes (KDIGO) Controversies Conference. Baigent C, Herrington WG, Coresh J, Landray MJ, Levin A, Perkovic V, Pfeffer MA, Rossing P, Walsh M, Wanner C, Wheeler DC, Winkelmayer WC, McMurray JJV; Kidney Int. 2017 Aug;92(2):297-305. doi: 10.1016/ j.kint.2017.04.019.

2 Young adults' perspectives on living with kidney failure: a systematic review and thematic synthesis of qualitative studies. Bailey PK, Hamilton AJ, Clissold RL, Inward CD, Caskey FJ, Ben-Shlomo Y, Owen-Smith A. BMJ Open. 2018 Jan 10;8(1):e019926. doi: 10.1136/bmjopen-2017019926.

3 United Kingdom Catheter Study - protocol synopsis. Briggs V, Solis-Trapala I, Wailoo A, McCullough K, Lambie M, Caskey FJ, Fotheringham J, Davies SJ, Wilkie M. Perit Dial Int. 2017 Sep 28. pii: pdi.2017-00083. doi: 10.3747/pdi.2017-00083.

4 The UK Renal Registry: making patient data matter. Evans KM, Pyart R, Steenkamp R, Caskey FJ. Br J Hosp Med (Lond). 2018 May 2;79(5):246248. doi: 10.12968/hmed.2018.79.5.246.

5 Relative risk versus absolute risk: one cannot be interpreted without the other. Noordzij M, van Diepen M, Caskey FC, Jager KJ. Nephrol Dial Transplant. 2017 Apr 1;32(suppl_2):ii13-ii18. doi: 10.1093/ndt/gfw465.

6 Continually improving standards of care: The UK Renal Registry as a translational public health tool. Plumb LA, Hamilton AJ, Inward CD, Ben-Shlomo Y, Caskey FJ. Pediatr Nephrol. 2018 Mar;33(3):373-380. doi: 10.1007/s00467-017-3688-2.

7 What are the risks and benefits of temporarily discontinuing medications to prevent acute kidney injury? A systematic review and meta-analysis. Whiting P, Morden A, Tomlinson LA, Caskey F, Blakeman T, Tomson C, Stone T, Richards A, Savoviæ J, Horwood J. BMJ Open. 2017 Apr 7;7(4):e012674. doi:10.1136/bmjopen-2016-012674. 
